\title{
Value and protection of geographical indications by the Japanese Wine Law
}

\author{
K. Ebihara ${ }^{1}$ and M. Omura ${ }^{2}$ \\ ${ }^{1}$ Department of Global Legal Studies, Meiji Gakuin University, 1-2-37 Shirokanedai, Minato-ku, 1088636 Tokyo, Japan \\ ${ }^{2}$ Department of Economics, Meiji Gakuin University
}

\begin{abstract}
Recently, Japanese wine law has changed dramatically. In October 2015, the definition of "Japan wine" and the labelling rules were introduced, and the registration guidelines for the geographical indication (GI) were formulated. Up to now, the Commissioner of the National Tax Agency has designated two wine GIs: "Yamanashi" and "Hokkaido". However, it is not easy for Japanese consumers to understand the value and the role of GI. The National Tax Agency, prefectures, municipal authorities and winery associations organise from time to time promotional events of GI wines to spread the notion of GI. Even though the majority of "Japan wine", including GI wine, is consumed in the internal market, it is necessary to protect the Japanese GIs in foreign countries. Due to the EU-Japan EPA that ensures the mutual protection of GIs, it is quite probable that the GI will play an important role in the export of Japanese wine, liquor and agricultural products.
\end{abstract}

\section{Introduction}

As a member state of the World Trade Organisation (WTO), Japan introduced the geographical indication system for liquor products in 1994, following the Agreement on Trade-Related Aspects of Intellectual Property Rights (TRIPS Agreement), but for a long time, this system was not applied in practice.

It is only in July 2013 that "Yamanashi", the first geographical indication of wine in Japan, was registered by the Commissioner of the National Tax Agency, the regulatory authority of wine market in Japan.

In October 2015, the definition of "Japan wine", that is, domestically produced wine that uses only grapes harvested in Japan, as well as the labelling rules applicable to all the"domestically produced wine" were introduced. At the same time, the new standards concerning geographical indications for liquors and registration guidelines were formulated by the National Tax Agency. These national rules are regarded as the essential elements of the Japanese Wine Law.

On the other hand, the Japanese Diet enacted a geographical indication law that recognizes GI protection for agricultural products in 2014. Nevertheless, this law, which has entered into force in June 2015, does not cover liquor products being sui generis. Therefore, Japanese GI system is characterised by this dualism.

\section{The new standards for wine}

The National Tax Agency issued, on 30th October 2015, the "Notice on Establishing Indication Standards Concerning Geographical Indications for Liquor", in order to clarify the process of registering geographical indications. This notice has been adopted pursuant to the Act concerning the Liquor Business Association that authorises the Commissioner of the National Tax Agency to formulate the labelling standards for liquor products.

\subsection{Application for $\mathrm{GI}$}

In Japan, the geographical indications for liquor products are granted by the Commissioner of the National Tax Agency upon application from a group of producers of the areas. Their consensus on the matter is indispensable for the application.

According to the new Standards, for wines with a geographical indication, at least $85 \%$ of the grapes used for its production should come exclusively from the geographical area and its production must take place in the area.

In order to apply for a geographical indication, the product should specify:

- the name and the demarcation of the geographical area concerned;

- the name and address of the authorities or bodies verifying the compliance with the provisions of the product specification;

- a description of the wine(s);

- a description of the quality, reputation or other specific characteristics of the product attributable to its geographical origin;

- a description of the causal interaction between the characteristics of the product and the geographical area;

- an indication of the wine grape variety or varieties;

- minimum sugar content of grape juice varied with the grape variety used;

- limits on permitted enrichment, acidification and de-acidification;

- maximum content of sulphur dioxide not more than 350 milligrams per kilogram of the product; 
- minimum alcoholic strength and its upper limit;

- minimum total acidity;

- maximum volatile acidity.

Whenever making a designation of geographical indication, the National Tax Agency shall notify the matter and the product specification concerned through its official website to seek public opinion. The Standards also stipulate that an apriori sensory test is compulsory for wine.

At the moment, "Yamanashi" and "Hokkaido" are designated as official geographical indications by the Commissioner of the National Tax Agency. Both are registered as prefectural level geographical indications (see Table 1). In the Japanese GI system, there is no distinction between Protected Designation of Origin (PDO) and Protected Geographical Indication (PGI).

\subsection{GI Yamanashi}

Probably, Yamanashi is one of the most well-known wine regions in Japan, because of its winemaking history and a large number of existing wineries.

To use the geographical indication "Yamanashi", the wine should be produced exclusively from grapes harvested in Yamanashi prefecture, and fermented and bottled in the same prefecture.

The wine can use 42 designated grape varieties listed on the product specification. Among Japanese grape varieties, Koshu, Muscat Bailey A, Black Queen, Kai Noir, Kai Blanc can be used. Concerning vitis vinifera varieties, Merlot, Cabernet Sauvignon, Pinot Noir, Chardonnay, Sauvignon Blanc and other major grape varieties are listed.

The minimum sugar content levels of grape juice are $14.0 \%$ for Koshu, $18.0 \%$ for vitis vinifera varieties and $16.0 \%$ for other grape varieties. Wine shall have an actual alcoholic content not less than $8.5 \%$ for dry wine and $4.5 \%$ for sweet wine.

The chaptalisation of wines is limited to $10 \mathrm{~g} / 100 \mathrm{~mL}$ for Koshu, $6 \mathrm{~g} / 100 \mathrm{~mL}$ for vitis vinifera varieties and $8 \mathrm{~g} / 100 \mathrm{~mL}$ for other grape varieties.

The wine must have a total acidity content of not less than 3.5 grams per litre. The maximum volatile acidity is $1.2 \mathrm{~g} / \mathrm{L}$ for red wine and $1.08 \mathrm{~g} / \mathrm{L}$ for white and rosé wines.

In Japan, a sensory test is compulsory for all GI wines. Thus, the Management Commission for GI "Yamanashi" conducts a quality and display review. Only wines that pass the test may use the "GI Yamanashi" label.

\subsection{GI Hokkaido}

Hokkaido is one of the most remarkable wine region in Japan in terms of quality and quantity. Its subarctic climate has been considered to be not favourable for grape production. Nevertheless, because of global warming and low level of rainfall in the summer, Hokkaido has become an ideal wine region in recent years. Availability of spacious land is also advantageous for winemakers and vine growers.

To use the geographical indication "Hokkaido", the wine should be produced exclusively from grapes harvested in Hokkaido prefecture, and fermented and bottled in the same prefecture.

The wine can use 57 designated grape varieties listed on the product specification, including Pinot Noir, Kerner, Niagara, Yamasachi, etc.
Table 1. The Japanese GIs registered by the Commissioner of the National Tax Agency (as of April 2019).

\begin{tabular}{|c|c|c|c|}
\hline Name & $\begin{array}{c}\text { Date of } \\
\text { Designation }\end{array}$ & $\begin{array}{c}\text { Geographical } \\
\text { Area }\end{array}$ & Category \\
\hline $\begin{array}{l}\text { Iki } \\
\text { 壱岐 }\end{array}$ & 30.06 .1995 & $\begin{array}{c}\text { Iki City } \\
\text { (Nagasaki Pref.) }\end{array}$ & Spirits \\
\hline $\begin{array}{l}\text { Kuma } \\
\text { 球磨 }\end{array}$ & 30.06 .1995 & $\begin{array}{c}\text { Kuma-gun and } \\
\text { Hitoyoshi City } \\
\text { (Kumamoto } \\
\text { Pref.) }\end{array}$ & Spirits \\
\hline $\begin{array}{l}\text { Ryukyu } \\
\text { 琉球 }\end{array}$ & 30.06 .1995 & Okinawa Pref. & Spirits \\
\hline $\begin{array}{l}\text { Satsuma } \\
\text { 薩摩 }\end{array}$ & 22.12 .2005 & $\begin{array}{c}\text { Kagoshima } \\
\text { Pref. except } \\
\text { Amami City and } \\
\text { Oshima County }\end{array}$ & Spirits \\
\hline $\begin{array}{l}\text { Hakusan } \\
\text { 白山 }\end{array}$ & 22.12 .2005 & $\begin{array}{c}\text { Hakusan City } \\
\text { (Ishikawa Pref.) }\end{array}$ & $\begin{array}{l}\text { Seishu } \\
\text { (Sake) }\end{array}$ \\
\hline $\begin{array}{l}\text { Yamanashi } \\
\text { 山梨 }\end{array}$ & 16.07 .2013 & Yamanashi Pref. & Wine \\
\hline $\begin{array}{l}\text { Nihonshu } \\
\text { / Japanese } \\
\text { Sake } \\
\text { 日本酒 }\end{array}$ & 25.12 .2015 & $\begin{array}{l}\text { The entire } \\
\text { country of Japan }\end{array}$ & $\begin{array}{l}\text { Seishu } \\
\text { (Sake) }\end{array}$ \\
\hline $\begin{array}{l}\text { Yamagata } \\
\text { 山形 }\end{array}$ & 16.12 .2016 & Yamagata Pref. & $\begin{array}{l}\text { Seishu } \\
\text { (Sake) }\end{array}$ \\
\hline $\begin{array}{c}\text { Hokkaido } \\
\text { 北海道 }\end{array}$ & 28.06 .2018 & Hokkaido Pref. & Wine \\
\hline $\begin{array}{l}\text { Nadagogo } \\
\text { 灘五郷 }\end{array}$ & 28.06 .2018 & $\begin{array}{c}\text { Kobe City } \\
\text { (Nada-ku and } \\
\text { Higashinada- } \\
\text { ku), Ashiya City } \\
\text { and } \\
\text { Nishinomiya } \\
\text { City (Hyogo } \\
\text { Pref.) }\end{array}$ & $\begin{array}{l}\text { Seishu } \\
\text { (Sake) }\end{array}$ \\
\hline
\end{tabular}

The minimum sugar content levels of grape juice are $16.0 \%$ for vitis vinifera varieties, $13.0 \%$ for vitis labrusca varieties and $15.0 \%$ for vitis coignetiae varieties (Yamabudo) and hybrids.

The wine is required to have an actual alcoholic content not more than $14.5 \%$; a total acidity content of not less than $5.2 \mathrm{~g} / \mathrm{L}$ for red wine and $5.8 \mathrm{~g} / \mathrm{L}$ for white and rosé wines. The maximum volatile acidity is $1.5 \mathrm{~g} / \mathrm{L}$.

The regulatory body of GI "Hokkaido" is the Management Commission for GI "Hokkaido", which conducts quality examination including a compulsory sensory test.

\section{Regional brand value of $\mathrm{Gl}$ and its protection}

\subsection{GI wine and Japanese consumers}

In principle, the GI serves to protect regional brand values. However, it is not easy for Japanese consumers to understand the value and the role of the newly introduced system of geographical indication. In order to spread the notion of geographical indication and registered GIs, the National Tax Agency, prefectures, municipal authorities and also some winery associations organise from time to time promotional events of GI wine.

Concerning GI Hokkaido, an official seal for certification should be pasted on the bottle. This visible seal 
Table 2. The Japanese GIs protected in the EU (Agreement between the European Union and Japan for an Economic Partnership, Section B of Part 2 of Annex 14-B).

\begin{tabular}{|c|c|c|}
\hline $\begin{array}{c}\text { Name to be } \\
\text { protected }\end{array}$ & $\begin{array}{c}\text { Transcription } \\
\text { into Latin } \\
\text { alphabet }\end{array}$ & Category \\
\hline 壱岐 & Iki & Spirits \\
\hline 球磨 & Kuma & Spirits \\
\hline 琉球 & Ryukyu & Spirits \\
\hline 薩摩 & Satsuma & Spirits \\
\hline 白山 & Hakusan & Seishu (Sake) \\
\hline 山梨 & Yamanashi & Wine \\
\hline $\begin{array}{c}\text { 日本酒 } \\
\text { (Japanese } \\
\text { Sake) }\end{array}$ & Nihonshu & Seishu (Sake) \\
\hline 山形 & Yamagata & Seishu (Sake) \\
\hline
\end{tabular}

helps consumers to differentiate the GI wines from other ordinary wines.

At present, the potential production volume by the producers settled in Yamanashi and Hokkaido prefectures represents about a half of the "Japan wine". Apart from Yamanashi and Hokkaido, there are few renowned wine regions such as Nagano, Osaka, Iwate, which organise wine festivals every year. A designation of municipal level GI is also probable for some municipalities: Katsunuma in Koshu City (Yamanashi Pref.), Shiojiri City and Toumi City (Nagano Pref.), Yoichi Town (Hokkaido Pref.), etc. These municipalities are already well known to consumers, because of their high quality wine and outstanding producers.

\subsection{Development of protection}

In Japan, the GIs are protected by the Act concerning Liquor Business Association, which applies sanctions in case of violation of Standards. As a domestic law, the GI Standards cover only Japanese territory. However, the Economic Partnership Agreement (EPA) between the European Union and Japan, which entered into force in February 2019, ensure the mutual protection of GIs.

The article 14.24 of the Agreement stipulates that "following the completion of an opposition procedure and an examination of the geographical indications of Japan listed in Section B of Part 1 and Section B of Part 2 of Annex 14-B, the European Union shall recognize that those indications are geographical indications within the meaning of paragraph 1 of Article 22 of the
TRIPS Agreement and that they have been registered by Japan under the system referred to in Article 14.23. The European Union shall protect those geographical indications in accordance with this Sub-Section".

As a consequence, the geographical indications of Japanese liquor products shown in Table 2 are protected in the EU.

These protections are not limited to wines and spirits. The EU approved 48 GIs for Japanese agricultural, forestry and fishery products as well as foodstuffs excluding alcoholic beverages.

Following the article 14.24 of the Agreement, Japan provides a high-level TRIPS Article 23 protection for 139 EU-proposed GIs for wine, spirits and other alcoholic beverages, and also 70 EU-proposed GIs for agricultural items.

Furthermore, some Japanese GIs are protected in countries other than the EU member states. For example, GI "Satsuma" is protected in Mexico, Chili and Peru. GI "Iki", "Kuma" and "Ryukyu" are protected in Mexico and Peru. Thailand is in favour of mutual GI protections for agricultural items.

As for Janapese wine, there is no protection in foreign countries except for in the EU. Within the framework of bilateral agreements, it is probable that Japanese wine GIs will be protected in Mexico, Chili or Peru.

\section{Conclusions}

Even though the GI system was unfamiliar to Japanese consumers, Japan established the GI system for liquor products in 1994 and, recently, the number of designated GIs is increasing. The EU-Japan EPA is expected to accelerate this trend for liquor and agricultural products.

It is true that the majority of "Japan wine", including GI wine, is consumed in the domestic market. However, it is necessary to protect the Japanese GIs even in foreign countries. Thus, Japanese government has to ensure the mutual protection of GIs by bilateral or multilateral agreements.

Some wine producers in Yamanashi and Hokkaido engage in promotion of their wines in foreign countries in Europe and Asia and they make use of the GI system. It is quite probable that the GI will play an increasingly important role in the export of Japanese wine, liquor and agricultural products.

\section{References}

[1] K. Ebihara, Introduction au droit viti-vinicole (Kohyusha, Tokyo, 2014)

[2] H. Yamamoto, T. Takahashi, K. Ebihara, Le droit $d u$ vin dans le monde (Nippon Hyoron Sha, Tokyo, 2009)

[3] T. Takahashi, K. Harada, K. Kobayashi, H. Sato, Wines of Japan (Ikaros Publications, Tokyo, 2017) 